\title{
Nanotoxicology: Nano Toxicity in Humans
}

\author{
Sadique Hussain
}

School of Pharmaceutical Sciences, Jaipur National University, Jagatpura (302017), Jaipur, Rajasthan, India.

*Corresponding Author: Sadique Hussain, School of Pharmaceutical Sciences, Jaipur National University, Jagatpura (302017), Jaipur, Rajasthan, India

Received date: November 23, 2021; Accepted date: December 15, 2021; Published date: January 04, 2022

Citation: Sadique Hussain, (2022) Nanotoxicology: Nano Toxicity In Humans. J. Pharmaceutics and Pharmacology Research. 5(1); DOI: 10.31579/2693-7247/059

Copyright: ( $) 2022$ Sadique Hussain, This is an open access article distributed under the Creative Commons Attribution License, which permits unrestricted use, distribution, and reproduction in any medium, provided the original work is properly cited.

\begin{abstract}
Nanoparticles (NPs) have attracted a lot of attention in the fields of electronics, biology, and astronautics because of their unique physicochemical and electrical characteristics. NPs are materials with at least one dimension of fewer than 100 nanometres that are commercially manufactured (Bahadar et al., 2016; Vishwakarma et al., 2010). In the medical field, drugs, proteins, DNA, and monoclonal antibodies are all being delivered via NPs(Hussain et al., 2021).
\end{abstract}

Key words: nanotoxicology; physicochemical; biomedical use

\section{Introduction}

Although the name "nanotoxicology" may cause concern among the general public, it is a relatively young discipline of toxicology that tackles the information gap about toxicity caused by NPs. This new area of toxicology, according to Priyanka et al., presents techniques to access the toxicity generated by nanoparticles. For toxicity evaluation in people and the environment, this section comprises a fundamental understanding of the physicochemical impacts of NPs and their routes of exposure/uptake processes (Ganguly et al., 2018). The overall purpose of nanotoxicology is to define criteria for making safe nanoparticles. This necessitates a thorough, systemic approach to examining NP toxicity and its impact on cells, tissues, organs, and the entire organism(Donaldson et al., n.d.). The physical and chemical features of NPs, such as size, shape, specific surface area, surface charge, catalytic activity, and the presence or absence of a shell and active groups on the surface, all influence their toxicity(Sukhanova et al., 2018). Because of their small dimensions and unique features, NPs are frequently exploited as nanomedicine and drug nanocarriers. Their toxicity towards normal, healthy human cells, tissues, and organs might be due to their size, shape, surface functional groups, and dose-dependent characteristics. Numerous researchers have discovered that chemically synthesized NPs are more harmful to human cells than biosynthesized NPs with biocompatible surface functional groups due to the presence of synthetic chemicals as surface functional and capping agents. On the other hand, certain biosynthesized NPs can be harmful when they react with cells and disintegrate into simpler forms or accumulate (Egbuna et al., 2021). Nanotoxicology has just recently arisen, years after NPs first boom when many nanomaterials had already been used in a variety of industrial processes and products(Elsaesser \& Howard, 2012).
NPs' physiochemical qualities have an impact on how they interact with cells and, as a result, on their total potential toxicity. Understanding these qualities can lead to the creation of NPs that are safer. Recent research has begun to pinpoint the characteristics that make certain NPs more dangerous than others. In theory, particle size might have a role in cytotoxicity. Smaller NPs have a bigger specific surface area (SSA) than larger NPs with the same mass, and hence a more accessible surface area to interact with biological components such nucleic acids, proteins, fatty acids, and carbohydrates. Because of its tiny size, it is more likely to infiltrate cells and cause harm. Toxicity was discovered to be a function of both size and SSA in certain NPs. When evaluating the number of reactive oxygen species (ROS) generation per surface area within a given size range, the size of anatase $\mathrm{TiO} 2$ was demonstrated to correlate with ROS production(Huang et al., 2017). In summary, the following are the most typical pathways of NPs cytotoxicity (Sukhanova et al., 2018):

1. NPs can induce oxidation by forming reactive oxygen species (ROS) and other free radicals;

2. NPs can perforate cell membranes, causing harm.

3. NPs disrupt intracellular transport and cell division by damaging cytoskeleton components.

4. NPs disrupt transcription and damage DNA, speeding up the mutagenesis process;

5. NPs harm mitochondria and disrupt their metabolism, resulting in an energy imbalance in the cell;

6. NPs prevent the development of lysosomes, impairing autophagy and macromolecule breakdown as well as causing apoptosis; 
7. NPs alter the structure of membrane proteins and disrupt the movement of substances into and out of cells, including intercellular transport;

8. NPs trigger the production of inflammatory mediators by disrupting normal cell, tissue, and organ metabolism;

NPs' structure and physicochemical characteristics must be extensively defined and understood to accurately assess NPs'safety. To develop particular nanoparticle structure-activity/toxicity functional connections, reported harmful effects can be better linked to certain NPs features. Because NPs structural features influence toxicity, evaluating the safety of NPs with substantial changes in physicochemical qualities, as observed in natural and accidental nanoparticles, is considerably more difficult(Yang et al., 2021).

\begin{tabular}{|c|c|c|c|c|c|}
\hline $\begin{array}{l}\text { Nanoparticle } \\
\text { class and type }\end{array}$ & $\begin{array}{l}\text { Exposure route, } \\
\text { dose, duration, } \\
\text { number of humans } \\
\text { subjects }\end{array}$ & Adverse effect & $\begin{array}{l}\text { Toxicity } \\
\text { mechanism }\end{array}$ & Toxicity assessment & Reference(s) \\
\hline $\begin{array}{l}\text { Incidental } \\
\mathrm{Ag}\end{array}$ & $\begin{array}{l}\text { Inhalation } \\
\text { NA } \\
\text { Chronic } \\
76 \text { human subjects }\end{array}$ & Genotoxicity & $\begin{array}{l}\text { DNA damage in } \\
\text { mononuclear } \\
\text { leukocytes due to } \\
\text { oxidative stress- } \\
\text { induced } \\
\text { by Ag nanoparticles }\end{array}$ & $\begin{array}{l}\text { Blood analysis for } \\
\text { DNA } \\
\text { damage using alkaline } \\
\text { comet assay and } \\
\text { analysis } \\
\text { of total antioxidant } \\
\text { status, total oxidant } \\
\text { status, total thiol, and } \\
\text { ceruloplasmin in } \\
\text { human } \\
\text { blood plasma samples }\end{array}$ & $\begin{array}{l}\text { (Aktepe et al., } \\
\text { 2015) }\end{array}$ \\
\hline $\begin{array}{l}\text { Engineered } \\
\text { PEGylated } \\
\text { liposomes } \\
\text { (Doxil, } \\
\sim 100 \mathrm{~nm} \text { ) }\end{array}$ & $\begin{array}{l}\text { IV } \\
40-306 \mathrm{mg} \\
\text { Acute (infusion for } \\
1 \mathrm{~h} \text { ) } \\
29 \text { human subjects }\end{array}$ & Immunotoxicity & $\begin{array}{l}\text { Hypersensitivity } \\
\text { reaction } \\
\text { and anaphylatoxin } \\
\text { release due to } \\
\text { complement } \\
\text { activation } \\
\text { of PEGylated } \\
\text { liposomes }\end{array}$ & $\begin{array}{l}\text { Analysis of human } \\
\text { blood } \\
\text { samples for } \\
\text { complement } \\
\text { terminal complex } \\
\text { (SC5b-9) to correlate } \\
\text { complement } \\
\text { activation } \\
\text { with hypersensitivity } \\
\text { reaction }\end{array}$ & $\begin{array}{l}\text { (Chanan-Khan et } \\
\text { al., 2003) }\end{array}$ \\
\hline $\begin{array}{l}\text { Natural } \\
\text { Fe3O4 } \\
(<20 \mathrm{~nm})\end{array}$ & $\begin{array}{l}\text { NA } \\
\text { NA } \\
\text { Chronic (many } \\
\text { years) } \\
22 \text { human subjects }\end{array}$ & Neurotoxicity & $\begin{array}{l}\text { Abnormal, age- } \\
\text { associated } \\
\text { biomineralization of } \\
\mathrm{Fe} 3 \mathrm{O} 4 \text { in the brain }\end{array}$ & $\begin{array}{l}\text { Quantitative } \\
\text { magnetometry; } \\
\text { correlation between } \\
\text { Fe3O4 nanoparticle } \\
\text { concentration in the } \\
\text { human brain and } \\
\text { Alzheimer's disease }\end{array}$ & $\begin{array}{l}\text { (Pankhurst et al., } \\
\text { 2008) }\end{array}$ \\
\hline $\begin{array}{l}\text { Incidental } \\
\text { Chemically } \\
\text { complex } \\
\text { mixtures } \\
(10-80 \mathrm{~nm})\end{array}$ & $\begin{array}{l}\text { Inhalation } \\
30,000 \mathrm{NPs} / \mathrm{cm} 3 \\
(>10 \\
\text { times background } \\
\text { levels) } \\
\text { Acute (6 h/day for } \\
3 \text { days) } \\
17 \text { human subjects }\end{array}$ & $\begin{array}{l}\text { Pulmonary } \\
\text { toxicity }\end{array}$ & $\begin{array}{l}\text { Upper airway } \\
\text { inflammation and } \\
\text { systemic oxidative } \\
\text { stress with } \\
\text { generation } \\
\text { of proinflammatory } \\
\text { cytokines }\end{array}$ & $\begin{array}{l}\text { Analysis of } 14 \\
\text { cytokines in } \\
\text { nasal lavage samples } \\
\text { and } \\
\text { analysis of } 8-\mathrm{OH}-\mathrm{dG} \\
\text { and creatinine in } \\
\text { human } \\
\text { urine samples }\end{array}$ & $\begin{array}{l}\text { (Khatri et al., } \\
\text { 2013) }\end{array}$ \\
\hline $\begin{array}{l}\text { Incidental } \\
\text { Diesel exhaust } \\
\text { nanoparticles } \\
(<100 \mathrm{~nm})\end{array}$ & $\begin{array}{l}\text { Inhalation } \\
1.2 \times 106 \mathrm{NPs} / \mathrm{cm} 3 \\
\text { Acute (up to } 14 \\
\text { days) } \\
16 \text { human subjects }\end{array}$ & $\begin{array}{l}\text { Vascular } \\
\text { dysfunction }\end{array}$ & $\begin{array}{l}\text { Increased systolic } \\
\text { blood } \\
\text { pressure and } \\
\text { attenuated } \\
\text { vasodilation due to } \\
\text { nanoparticle- } \\
\text { induced } \\
\text { vascular } \\
\text { oxidative stress }\end{array}$ & $\begin{array}{l}\text { Measurement of } \\
\text { forearm } \\
\text { blood flow and blood } \\
\text { pressure and } \\
\text { biomarker } \\
\text { analysis of human } \\
\text { blood } \\
\text { samples }\end{array}$ & $\begin{array}{l}\text { (Mills et al., } \\
\text { 2011) }\end{array}$ \\
\hline
\end{tabular}




\section{Conclusion}

Because of their physicochemical and behavioral distinctiveness, nanoparticles have found extensive biomedical use, yet worries about their harmful consequences in the biological system are now attracting the attention of the worldwide health community. This involves the research and comprehension of the impacts based on the cellular and molecular processes by which they produce these effects. As a result, drawing broad generalizations about nanoparticle toxicity is difficult since nanotoxicity is based on complicated interactions between many physicochemical features and the associated biological context. The public is concerned about widespread human exposure to nanoparticles. As a result, improved techniques for assessing the safety of nanoparticles are required. The current state of knowledge on the impacts of nanomaterials on humans is quite limited.

\section{Conflicts Of Interest}

The authors declare no conflicts of interest.

\section{Funding}

None.

\section{References}

1. Aktepe, N, Kocyigit, A, Yukselten, Y., Taskin, A., Keskin, C., \& Celik, H. (2015). Increased DNA Damage and Oxidative Stress Among Silver Jewelry Workers. Biological Trace Element Research, 164(2), 185-191.

2. Bahadar, H., Maqbool, F., Niaz, K., \& Abdollahi, M. (2016). Toxicity of Nanoparticles and an Overview of Current Experimental Models. Iranian Biomedical Journal, 20(1), 1.

3. Chanan-Khan, A., Szebeni, J., Savay, S., Liebes, L., Rafique, N. M., Alving, C. R., \& Muggia, F. M. (2003). Complement activation following first exposure to pegylated liposomal doxorubicin (Doxil): possible role in hypersensitivity reactions. Annals of Oncology: Official Journal of the European Society for Medical Oncology, 14(9), 1430-1437.

4. Donaldson, N. K., Stone, V., Tran, C. L., Kreyling, W., \& A Borm, P. J. (n.d.). Toxicology A new frontier in particle toxicology relevant to both the workplace and general environment and to consumer safety.
5. Egbuna, C., Parmar, V. K., Jeevanandam, J., Ezzat, S. M., PatrickIwuanyanwu,et al. (2021). Toxicity of Nanoparticles in Biomedical Application: Nanotoxicology. Journal of Toxicology, 2021.

6. Elsaesser, A., \& Howard, C. V. (2012). Toxicology of nanoparticles. Advanced Drug Delivery Reviews, 64(2), 129-137

7. Ganguly, P., Breen, A., \& Pillai, S. C. (2018). Toxicity of Nanomaterials: Exposure, Pathways, Assessment, and Recent Advances. ACS Biomaterials Science \& Engineering, 4(7), 22372275.

8. Huang, Y. W., Cambre, M., \& Lee, H. J. (2017). The Toxicity of Nanoparticles Depends on Multiple Molecular and Physicochemical Mechanisms. International Journal of Molecular Sciences, 18(12).

9. Hussain, M. S., Sharma, P., Dhanjal, D. S., Khurana, N., Vyas, M., Sharma, N., Mehta, M., Tambuwala, M. M.et al (2021). Nanotechnology based advanced therapeutic strategies for targeting interleukins in chronic respiratory diseases. ChemicoBiological Interactions, 348.

10. Khatri, M., Bello, D., Gaines, P., Martin, J., Pal, A. K., Gore, R., \&Woskie, S. (2013). Nanoparticles from photocopiers induce oxidative stress and upper respiratory tract inflammation in healthy volunteers. Nanotoxicology, 7(5), 1014-1027.

11. Mills, N. L., Miller, M. R., Lucking, A. J., Beveridge, J., Flint, L., Boere, \& Newby, D. E. (2011). Combustion-derived nanoparticulate induces the adverse vascular effects of diesel exhaust inhalation. European Heart Journal, 32(21), 2660-2671.

12. Pankhurst, Q., Hautot, D., Khan, N., \& Dobson, J. (2008). Increased levels of magnetic iron compounds in Alzheimer's disease. Journal of Alzheimer's Disease: JAD, 13(1), 49-52.

13. Sukhanova, A., Bozrova, S., Sokolov, P., Berestovoy, M., Karaulov, A., \& Nabiev, I. (2018). Dependence of Nanoparticle Toxicity on Their Physical and Chemical Properties. Nanoscale Research Letters 2018 13:1, 13(1), 1-21.

14. Vishwakarma, V., Samal, S., Eng, N. M.-J. M. M. C.,(2010), undefined. (2010). Safety and risk associated with nanoparticlesa review. Citeseer, 9(5), 455-459.

15. Yang, W., Wang, L., Mettenbrink, E. M., Deangelis, P. L., \& Wilhelm, S. (2021). Nanoparticle Toxicology. Https://Doi.Org/10.1146/Annurev-Pharmtox-032320-110338, 61, 269-289.

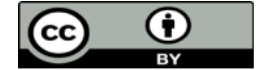

This work is licensed under Creative Commons Attribution 4.0 License

To Submit Your Article Click Here: Submit Manuscript

DOI: $10.31579 / 2693-7247 / 059$
Ready to submit your research? Choose Auctores and benefit from:

$>$ fast, convenient online submission

$>$ rigorous peer review by experienced research in your field

$>$ rapid publication on acceptance

$>$ authors retain copyrights

$>$ unique DOI for all articles

$>$ immediate, unrestricted online access

At Auctores, research is always in progress.

Learn more https://auctoresonline.org/journals/pharmaceutics-andpharmacology-research 